Letter to the Editor

\title{
Correction of aggregative thrombocytes activity in patients with unstable angina by THz irradiation of nitrogen oxide occurrence at in vitro conditions
}

\author{
Vyacheslav F. Kirichuk, Evgeny V. Andronov
}

Saratov State Medical University n.a. V.I. Razumovsky, Saratov, Russia

Received 30 May 2013, Accepted 20 September 2013

(C) 2013, Kirichuk V.F., Andronov E.V.

(C) 2013, Russian Open Medical Journal

Abstract: There had been shown a normalizing effect of THz radiation of MEAS (molecular emission and absorption spectrum) of $400 \mathrm{GHz}$ nitrogen oxide occurrence on aggregation parameters of thrombocytes in patients with unstable angina at in vitro conditions. 180 patients with an unstable angina had been involved in to the research.

Keywords: thrombocytes, unstable angina, THz irradiation, nitrogen oxide

Cite as Kirichuk VF, Andronov EV. Correction of aggregative thrombocytes activity in patients with unstable angina by THz irradiation of nitrogen oxide occurrence at in vitro conditions. Russian Open Medical Journal 2013; 2: 0409.

Correspondence to Prof. Vyacheslav F. Kirichuk. Address: Department of normal physiology n.a. I.A. Chuevsky, Saratov State Medical University n.a. V.I. Razumovsky, 112, Bolshaya Kazachiya str., Saratov, 410012, Russia. E-mail: normalf@yandex.ru

\section{Introduction}

Conversion modern technologies of bioenergoinformational exposure had indicated that a human organism is a self-adjusting and self-organizing system consisting of hierarchically self-similar cell structures.

In natural environment there is no monochromatic irradiations of the extremely high frequency band (EHF band), as they are lost to the atmosphere, water and aquatic mediums. This circumstance, taking into account a high information capacity, made some scientists focus their attention on it and came up original ideas of a significant role of electromagnetic waves (EMW) of EHF band in live system homeostasis support [1].

Electromagnetic waves of EHF band have been using in medical practice for more than 30 years. These are electromagnetic waves of $30-300 \mathrm{GHz}$ occurrence [1].

This band has a variety of biological advantages. In experimental sets [2] there was displayed that cell during its vital process produces electromagnetic waves of a very wide band. In condition of a normal cell function the waves of the EHF band are of a noise character [2]. Certain electrical symmetry is typical to cells of an organism. This electrical symmetry is destroyed when there is a cell function failure. According to Le Chatelier's principle cells generate coherent electromagnetic waves of EHF. The aim of these waves is normalize the cell function [3].

It is expected that the exposure of the waves of EHF imitates cell regulating properties, normalize the defected cell function $[4,5]$. So, there was fixed a significant reduction of initially high free heparine level produced by granule cells of tissues and basophils [6].

The major point of the EHF waves is membrane-informational system $[7,8]$ which influences cell membranes, stimulates its lipid layer and protein components stirring [8], changing the cell functional activity.

It is known that cells in their physiological norm are not as sensible to EHF waves as cells with a pathological functional defect [2]. According to this idea, for studying the EHF waves exposure there should be used those cells for the experiment which function had been changed by some pathology.

The conception of the formed blood elements as of the primary aim of the EHF irradiation determines a specific interest of the scientists to the features of human erythrocytes and thrombocytes reaction on millimeter exposure [5].

To correct high aggregative thrombocytes activity in different forms of cardiac pathology (stable and unstable angina) the of $\mathrm{THz}$ radiation of MEAS (molecular emission and absorption spectrum) of $150.176-150.664 \mathrm{GHz}$ nitrogen oxide occurrence [9-12] is used. Nitrogen oxide is a vasodilator, strong hemostasis factor and thrombocytes aggregation inhibitor [13-17].

After the performed experiments there had been indicated a significant reduction of the initial free heparine level in the patients with unstable angina, their blood was under EHF irradiation at in vitro conditions [6].

Nitrogen oxide together with molecular emission and absorption spectrums of $150.176-150.664 \mathrm{GHz}$ and $240 \mathrm{GHz}$ occurrence and $400 \mathrm{GHz}$ occurrence [18]. So, we can suppose that reaction ability of endogenic NO molecules in biological media, for example, in thrombocytes rich plasma, will be maximal on this frequency.

Therefore, the research aimed to study the effect of $\mathrm{THz}$ radiation of MEAS of $400 \mathrm{GHz}$ occurrence on a thrombocytes functional activity in the patients with unstable angina at in vitro conditions, in natural electromagnetic field. 


\section{Material and Methods}

There had been studied changes in thrombocytes functional activity of 180 people with unstable angina under the radiation of MEAS of $400 \mathrm{GHz}$ occurrence at in vitro conditions. The thrombocytes rich plasma (TRP) was under the radiation of MEAS of $400 \mathrm{GHz}$ occurrence (the power density $1 \mathrm{~mW} / \mathrm{cm}^{2}$ ) in the natural electromagnetic field. Median cubital vein blood sampling had been performed at first 6-12 hours after hospitalization (before specific therapy).

There were the following criteria of involving into the experiment: administration to the emergency cardiac department with unstable angina appeared during last 48 hours in the forms: rest angina (pain progressing in rest and in minimal strength, more than 5 minutes and less than 30 minutes); effort angina (in activity which had not caused it before); increase of angina episodes after confirming in ECG (T-wave inversion, ST segment increase more than $0.5 \mathrm{~mm}$ : not enough to detect an acute myocardial infarction).

There were the following criteria of excluding out of the experiment: incipient postinfarction angina; new-oneset angina; new insults (less than 6 months); age is older than 70 years; the weight of the patients is $40 \mathrm{~kg}$ or more $110 \mathrm{~kg}$; blockade of the left bundle of atrioventricular bundle (except the initial obstinate blockade); ST segment increase more than $1 \mathrm{~mm}$ in two contiguous ECG leads; implanted cardiostimulator; renal failure (creatinine more than $200 \mathrm{mcmol} / \mathrm{l}$ ); thrombocytopenia (less than $\left.150 * 10^{9} / \mathrm{l}\right)$; liver failure; bacterial endocarditis; native or nonheritable hemostasis pathology.

All of the patients signed a written consent of taking part in the research which encluded clinical examination, echocardiography, 12-lead ECG, biochemical blood counts (concentration of: urea, creatinine, sodium and kalium ions, glucose, lipids, and triglycerids).

The patients included into the research had been matched in age and sex characteristics. An average age was $55.6 \pm 0.93$ years.

There were 20 relatively healthy donors-subjects, an average age was $54.3 \pm 0.72$ years.

Functional thrombocytes activity (activation and aggregation) had been determined by aggregation laser analyzer "Biola-230 Ltd." interfaced with IBM-compatible computer and special MS Windows soft "Aggr» (SPC "Biola") [19].

$3.8 \%$ sodium citrate fluid was used as a blood anticoagulant in proportion 9:1. Thrombocytes rich plasma (TRP) to give, blood had been centrifuged in $1000 \mathrm{r} / \mathrm{min}$ mode during 10 minutes. TRP had been divided on two parts: experimental and control.

Experiments in studying the effect of $\mathrm{THz}$ irradiation of MEAS (molecular emission and absorption spectrum) of $400 \mathrm{GHz}$ nitrogen oxide occurrence on functional thrombocytes activity in patients with unstable angina had been first organized by quasioptical EHF generator of determinate noises.

The experimental TRP sample of the patients with unstable angina had been irradiated by $\mathrm{THz}$ waves during 15 minutes. The control TRP sample had not been irradiated and had been free of the air flow influence. The researches of the functional thrombocytes activity in experimental and control TRP sample had been performed simultaneously.

TRP in final concentration of $2.5 \mu \mathrm{m}$ ("Helena", Israel) had been used as an inducer. The inducer was thrown at the $30^{\text {th }}$ second from the beginning of the experiment.
Statistical analysis of the results had been done with the help of the Mann-Whitney U-test (Statistica 6.0 soft).

\section{Results and Discussion}

In the patients with unstable angina an increase of thrombocytes aggregation activity is fixed. This is reflected in statistically valid increase of the maximal speed of the most thrombocyte aggregate producing, maximal degree and aggregation speed comparing with the group of relatively healthy donors.

During the 15-minute $\mathrm{THz}$ irradiation of MEAS of $400 \mathrm{GHz}$ nitrogen oxide occurrence exposure on TRP in the patients with unstable angina at in vitro conditions, in natural electromagnetic field, there was a significant reduction of thrombocytes aggregation activity which was accompanied by statistically valid decrease of the maximal thrombocyte aggregate size, maximal speed of the most thrombocyte aggregate producing, maximal degree and aggregation speed.

In comparison of the exposure effect of the $\mathrm{THz}$ irradiation of $240 \mathrm{GHz}$ and $400 \mathrm{GHz}$ on thrombocytes aggregation activity in the patients with unstable angina, the following results had been received. The 15-minute $\mathrm{THz}$ irradiation of $240 \mathrm{GHz}$ caused the reduction of all thrombocytes aggregation parameters. It is important to point out that there was no recovery of functional thrombocytes activity up to the parameters of healthy people, but there was a significant decrease of aggregation activity in all parameters comparing with the control group. At the same time the results received after the TRP irradiating of $400 \mathrm{GHz}$ were closer to thrombocytes aggregation activity parameters comparing with the control group of relatively healthy donors.

Thrombocytes aggregation depends on the activation of membranous glycoprotein thrombocytes receptors IIb-Wa and developing of fibrinous bridges between them [20, 21]. An increase of fibrinogen concentration in blood leads to an increase of thrombocytes activity in the patients with unstable angina $[22,23]$.

It is possible that the mechanism of antiaggregative effect of $\mathrm{THz}$ irradiation of MEAS of $400 \mathrm{GHz}$ occurrence on thrombocytes in the patients with unstable angina is caused by NO-synthetase and guanilatcyclase influence, leading to nitrogen oxide producing and cyclic guanosine monophosphate which are strong antiaggregants [14]. We can also suppose that $\mathrm{THz}$ waves, as well as EHF irradiation, is a factor of stimulating of molecular receptors of cell membranes, in distributing of which in intracellular space, there is an exposure on negatively charged glycoprotein threads of glycocalix of cell membrane [24], including thrombocytes which leads to their functional activity.

Besides, it is well known that between $\mathrm{THz}$ electromagnetic waves and thrombocyte aggregates there is a resonance interaction [11]. In aggregation the value of aggregate increases, and when they achieve the size of wave length, they resonate, this leads to deaggregation of thrombocyte aggregates in the patients with unstable angina.

Conflict of interest: none declared.

Reference

1. Betsky OV, Deviatkov ND, Kislov VV. Low-intensity MM-waves in biology and medicine. Biomedical Radioelectronics 1998; (10): 13-29. [Article in Russian] 
2. Devyatkov ND, Golant ND, Betsky OV. MM-waves and their role in vital processes. In: Radio and communication. Moscow, Russia, 1991: 103108. [Text in Russian]

3. Golant ND. Successes of EHF-medicine. To 90 years of academician N.D. Devyatkov. In: Abstract book of Russian academic conference "Millimeter waves in biology and medicine", Moscow, Russia, 1997: 89. [Text in Russian]

4. Devyatkov ND, Arzumanov UL, Betskiy OV, et al. Usage of low-intensity electromagnetic waves in medicine. In: Abstract book of the $10^{\text {th }}$ Russian academic conference "Millimeter waves in biology and medicine", Moscow, Russia, 1995: 6-8. [Text in Russian]

5. Kirichuk VF, Golovacheva TV, Chizh AG. EHF therapy. Saratov State Medical University, Saratov, Russia, 1999. [Book in Russian]

6. Kirichuk VF, Parshina SS, Golovacheva TV. EMI in angina therapy: remote results. Millimeter waves in biology and medicine: book of abstracts of The 11th Russian international academic conference, Moscow, Russia, 1997: 20-22. [Text in Russian]

7. Golant ND. Problem of resonant effect of coherent electromagnetic irradiations of millimeter band on live organisms. Biophysics 1989; (2): 339-348. [Article in Russian]

8. Golant ND. Millimeter waves and their role in vital processes. In: Millimeter waves in medicine nonthermal intensity. Moscow, Russia, 1991: 545-547. [Text in Russian]

9. Kirichuk VF, Andronov EV, Maiborodin AV, et al. Thrombocytes of patients with unstable angina as excitatory cell of $\mathrm{THz}$ irradiation of nitrogen oxide occurrence. Cardiovascular Therapy and Prevention 2005; 4(6, part 2): 53-60. [Article in Russian]

10. Kirichuk VF, Andronov EV, Maiborodin AV, et al. Effect of $\mathrm{THz}$ irradiation spectrum of nitrogen oxide on functional thrombocyte activity in patients with unstable angina. Biomedical Radioelectronics 2004; (12): 10-15. [Article in Russian]

11. Kirichuk VF, Maĭborodin AV, Volin MV, Krenitskiĭ AP, Tupikin VD. Comparative evaluation of the efficiency of the effect of very high frequency electromagnetic waves on platelet functional activity. Tsitologiia 2001; 43(8): 755-758. (PMID: 11601390)

12. Kirichuk VF, Krenickij AP, Majborodin AP. Electrodynamic model of the interaction of terahertz waves and air pollution from biological media in crossed constant magnetic and electric fields. Biomedical Radioelectronics 2004; (11): 35-45. [Article in Russian]

13. Malyshev IY, Manukhina EB. Stress, adaptation, and nitric oxide. Biochemistry (Mosc) 1998; 63(7): 840-53. (PMID: 9721337).

14. Severina IS. Role of soluble guanylate cyclase in the molecular mechanism underlying the physiological effects of nitric oxide. Biochemistry (Mosc) 1998; 63(7): 794-801. (PMID: 9721331)

15. Chrapko WE, Jurasz $\mathrm{P}$, Radomski MW, Lara N, Archer SL, Le Mellédo JM. Decreased platelet nitric oxide synthase ac-tivity and plasma nitric oxide metabolites in major depressive disorder. Biol Psychiatry 2004; 56(2): 129-134. (doi:10.1016/j.biopsych.2004.03.003) (PMID: 15231445)

16. Furchgott RF, Jothianandan D. Endothelium-dependent and independent vasodilation in-volving cyclic GMP: relaxation induced by nitric oxide, carbon monoxide and light. Blood Vessels 1991; 28: 52-61. (PMID: 1848126)

17. Tomasiak $M$, Stelmach $H$, Rusak $T$, Wysocka J. Nitric oxide and platelet energy metabolism. Acta Biochim Pol 2004; 51(3): 789-803. (PMID: 15448739)

18. Betsky OV, Krenitsky AP, Maiborodin AV, Kirichuk VF. Biophysical effects of THz-band and perspectives of progress in a new direction in biomedical technologies. Biomedical Radioelectronics 2003; (12): 3-6. [Article in Russian]

19. Gabbasov ZA, Popkov EG, Gavrilov IU, et al. New high-sensitivity method of thrombocyte aggregation analyze. Laboratory Science 1989; (10): 15-18. [Article in Russian]

20. Byshevsky ASh, Galyan SL, Dementieva IA, et al. Thrombocytes. Tumen, Russia, 1996. [Book in Russian]
21. Kirichuk VF. Blood physiology. Saratov State Medical University, Saratov, Russia, 2002. [Book in Russian]

22. Voskoboi IV, Kirichuk VF, Yudanova LS. Vascular-thrombocytic condition of hemostasis in patients with different forms of angina. Russian Medical Newsletter 2000; (1): 32-36. [Article in Russian]

23. Kirichuk VF, Shvarts YuG. Parameters of vascular-thrombocytic hemostasis mechanism and the nearest prognosis of unstable angina. Cardiology (Mosc) 1998; 38(5): 14-17. [Article in Russian]

24. Adey WR. Bioeffects of mobile communication fields; possible mechanisms for cumulative dose. Mobile Communications Safety Telecommunications Technology \& Applications Series 1997: 95-131. (doi: 10.1007/978-1-4613-1205-5_4)

\section{Authors:}

Vyacheslav F. Kirichuk - MD, D.Sc. Professor, Honored Scientist of Russia, Head of Department of Normal Physiology n.a. I.A. Chuevsky, Saratov State Medical University n.a. V.I. Razumovsky, Saratov, Russia;

Evgeny V. Andronov - MD, D.Sc., Professor, Department of Normal Physiology n.a. I.A. Chuevsky, Saratov State Medical University n.a. V.I. Razumovsky, Saratov, Russia. 